POST-TRANSITIONAL JUSTIGE 



\section{CATH COLLINS}

\section{POST-TRANSITIONAL JUSTICE}

HUMAN RIGHTS TRIALS IN CHILE AND EL SALVADOR

The Pennsylvania State University Press

University Park, Pennsylvania 
Library of Congress Cataloging-in-Publication Data

Collins, Cath, political scientist.

Post-transitional justice : human rights trials in Chile and El Salvador / Cath Collins.

p. $\mathrm{cm}$.

Includes bibliographical references and index.

Summary: "Analyzes how activists, legal strategies, and judicial receptivity to human rights claims are constructing new accountability outcomes for human rights violations

in Chile and El Salvador"-Provided by publisher. ISBN 978-0-271-03687-8 (cloth : alk. paper)

1. Transitional justice.

2. Crimes against humanity.

3. Criminal liability (International law).

4. Transitional justice-Chile.

5. Human rights—Chile.

6. Transitional justice-El Savador.

7. Human rights-El Salvador.

I. Title.

K3240.C5935 2010

$345.7284^{\prime} 0235$ - dc22

2009053929

Copyright $\odot 2010$ The Pennsylvania State University

All rights reserved

Printed in the United States of America

Published by The Pennsylvania State University Press,

University Park, PA 16802-1003

The Pennsylvania State University Press is a member of the Association of American University Presses.

It is the policy of The Pennsylvania State University Press to use acid-free paper. Publications on uncoated stock satisfy the minimum requirements of American National Standard for Information Sciences-Permanence of Paper for Printed Library Material, ANSI Z39.48-1992.

This book is printed on Natures Natural, which contains $50 \%$ post-consumer waste. 
For Pedro and Pablo

ganaremos nosotros,

los más sencillos

ganaremos,

aunque tú no lo creas,

ganaremos

-P. NERUDA 
